\title{
Leaching pattern of phosphate glass fertilizers with different compositions under Soxhlet distillation conditions
}

\section{(Lixiviação de fertilizantes de vidros de fosfato com diferentes composiç̃̃es em condições de destilação com Soxhlet)}

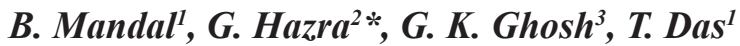 \\ ${ }^{1}$ University of Burdwan, Department of Chemistry, Burdwan-713104, W.B., India \\ ${ }^{2}$ Kalna College, Department of Chemistry, Kalna-713409, W.B., India \\ ${ }^{3}$ Visva-Bharati University, Department of Soil Science \& Agricultural Chemistry, Sriniketan-731236, W.B., India
}

\begin{abstract}
Glass fertilizers in the phosphate systems were melted at $900-950{ }^{\circ} \mathrm{C}$ with a soaking period of $1 \mathrm{~h}$. Leaching study of these glasses with a maximum time period of $300 \mathrm{~h}$ was conducted under Soxhlet distillation condition with distilled water. Weight loss and the leach rates of the glass fertilizer samples were calculated from BET surface area measurements. They were in the range of $6.3 \times 10^{-3}$ to $2.3 \times 10^{-3} \mathrm{~g} \cdot \mathrm{m}^{-2} \cdot \mathrm{h}^{-1}$ at $90^{\circ} \mathrm{C}$. The effect of different modifier ions like $\mathrm{Na}^{+}, \mathrm{Fe}^{3+}, \mathrm{Mg}^{2+}, \mathrm{Ca}^{2+}$, and $\mathrm{K}^{+}$in the basic phosphate networks on melting and time of melting has been found to be evident. The $\mathrm{pH}$ determination ranging from 4.80 up to 7.50 of the leachate solution at ambient temperature under varying time intervals showed interesting and regular variations. The leaching study of such glasses under Soxhlet condition showed $\mathrm{Ca}^{2+}, \mathrm{Mg}^{2+}$, and $\mathrm{K}^{+}$to be good candidates as modifier towards faster leaching. The findings have been corroborated in terms of ionic size, ionic radius, and hence the ionic potential of the modifier ions incorporated into the glass structure. The application of glass fertilizers was made on kharif paddy.
\end{abstract}

Keywords: phosphate glass, leaching, glass fertilizers, glass formers and modifiers, ionic potential, BET surface area.

Resumo

Fertilizantes de vidro nos sistemas de fosfato foram fundidos a 900-950 ${ }^{\circ} \mathrm{C}$ por $1 \mathrm{~h}$. Foi realizado estudo de lixiviação desses vidros com um período máximo de 300 h, em condição de destilação Soxhlet com água destilada. A perda de massa e as taxas de lixiviação das amostras de fertilizantes de vidro foram calculadas a partir de medições da área superficial de BET, que foram na faixa de $6,3.10^{-3}$ a 2,3.10-3 $\mathrm{g} \cdot \mathrm{m}^{-2} \cdot \mathrm{h}^{-1}$ a $90^{\circ} \mathrm{C}$. O efeito de diferentes ions modificadores, como $\mathrm{Na}^{+}, \mathrm{Fe}^{3+}, \mathrm{Mg}^{2+}, \mathrm{Ca}^{2+}$ e $\mathrm{K}^{+}$, nas redes de fosfato na fusão e no tempo de fusão foi evidente. A determinação do pH variando de 4,80 a 7,50 da solução de lixiviado à temperatura ambiente, em diferentes intervalos de tempo, mostrou variações interessantes e regulares. $O$ estudo de lixiviação desses vidros na condição de Soxhlet mostrou que $\mathrm{Ca}^{2+}, \mathrm{Mg}^{2+}$ e $\mathrm{K}^{+}$são bons candidatos como modificadores para uma lixiviação mais rápida. Os resultados foram corroborados em termos de tamanho iônico, raio iônico e, portanto, potencial iônico dos íons modificadores incorporados na estrutura do vidro. A aplicação de fertilizantes vítreos foi realizada na planta de arroz.

Palavras-chave: vidro de fosfato, lixiviação, fertilizantes de vidro, formadores e modificadores de vidro, potencial iônico, área superficial de BET.

\section{INTRODUCTION}

The chemical composition of various essential minerals and elements meant for the regular as well as hastened growth and nutrition of all plants is termed as fertilizer. The use of fertilizers in agriculture can be very useful for food production, but on the other hand, it may be harmful to the environment. Hence the only necessary amount of fertilizers can be used for successful vegetation. It means that we must use fertilizers, which are dissolved quickly as the nutrient requirement of plants. In this case, it is not a contamination hazard for the environment. All the fertilizers

*goutamhazra1@gmail.com

Dhttps://orcid.org/0000-0003-1908-3347 have been categorized into several types depending on their constituents, strength, and various other features (organic, inorganic, macronutrients, micronutrients, eco-friendly, controlled release glassy fertilizers, etc.) [1-3]. Pure phosphate glass (vitreous $\mathrm{P}_{2} \mathrm{O}_{5}$ ) is highly hygroscopic and is not appropriate for the application. The properties of this glass can be improved by the addition of different network modifiers - alkali and alkaline earth oxides. In that way, the multi-component phosphate-based glasses or glass-ceramics having many specific properties can be obtained. As such, these materials can find wide technological applications $[4,5]$. As reported earlier, the phosphate glasses of various compositions possess bioactivity and can be used as bio or eco-materials. Calcium phosphate glasses and glass ceramics for the bone implants in surgery and dentistry 
are well-known biomaterials $[6,7]$. Recently, because of gradual solubility, the attention was paid to the phosphatebased glasses, which can be used as new ecologically safe fertilizers $[8,9]$. The fact is that conventional technologies for land cultivation based on the application of traditional mineral fertilizers are responsible for the pollution of the environment.

The main advantage of glasses is the possibility to change their chemical composition by the addition of new elements in different quantities. Therefore, the kinetics and mechanism of the dissolution process can be tailored as needed [10]. In the case of plant nutrition, it is important that the release rates of glass components are equal to the absorption rates of plants or microorganisms [11]. In this way, the possible damaging effects of accumulation or deficiency of elements can be avoided. In this context, a glass fertilizer can take a dual role. In addition, as the leach resistance of glass is very high, i.e., when applied to a soil, the fertilizer is released very slowly, satisfying the optimum level of requirement with no misuse. It has been found that when such fertilizer is applied on tree-like mango remains 20-25 years at the root and it grows and gives fruits with a single charge of fertilizer [12]. There are two-fold advantages to incorporate the ingredients into a glass fertilizer: a) a glass can accommodate almost all the elements of the periodic table (secular matrix); and b) the leach resistance of glass which may vary is very high, i.e., it is not washout easily in water. Glass fertilizer slowly distributed into the root of the plant/crops is distributed thus into fruits of the crops, and in due course, it flourishes. The excess of the amount of glassy fertilizer remains in the soil and help for the next two batches of the crops [12]. Glass fertilizers (GF) are a new type of advanced and controlledrelease fertilizer made from glass matrices containing the

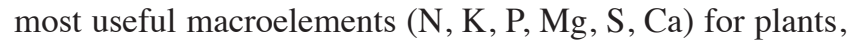
and also incorporate some microelements $\mathrm{B}, \mathrm{Fe}, \mathrm{Mo}, \mathrm{Cu}$, $\mathrm{Zn}, \mathrm{Mn}$ ) required for the correct growth and development of crops or plants $[1,12,13]$.

The main advantages of a new type of fertilizers against conventional fertilizers are increased grade of assimilation by plants, do not release insoluble compounds in soil, and remain in the soil during the entire period of plant development and do not pollute the phreatic water [14-17]. At the same time, these fertilizers have special peculiarities: controlled solubility in the time for many vegetable cycles; possibility to incorporate in the vitreous matrix many useful microelements [18]; do not contain toxic compounds; and do not release insoluble residues [19]. The use of glass fertilizers offers a lot of advantages as a result of: a) low or controlled solubility avoids underground water pollution; b) the soil $\mathrm{pH}$ can be regulated by the $\mathrm{pH}$ of the glass matrix; and c) none releases acid anions $\left(\mathrm{Cl}^{-}, \mathrm{SO}_{4}{ }^{2-}\right)$ which are harmful to plants, so there is no risk of soil burning when they are incorrectly dosed. The objective of this study is related to the leaching study of the phosphate glass fertilizers with different compositions under Soxhlet distillation conditions. The leaching study of these glasses up to $300 \mathrm{~h}$ was conducted. The variation of physical and chemical properties was taken into account with the changes in ionic charges and ionic radii and hence ionic potentials of different modifier ions, the source of which are the respective modifier oxides, viz. $\mathrm{MgO}, \mathrm{CaO}, \mathrm{Fe}_{2} \mathrm{O}_{3}$, $\mathrm{ZnO}$, and $\mathrm{MoO}_{3}$ for different glass systems.

\section{EXPERIMENTAL}

Preparation of glass batches and melting operation: the glass batches used in the present study were prepared from the ingredients like ammonium dihydrogen orthophosphate [ $\left(\mathrm{NH}_{4}\right) \mathrm{H}_{2} \mathrm{PO}_{4}, \mathrm{AR}$ grade, HI Media Lab., Mumbai], magnesium oxide (MgO, AR grade, Merck Life Sci., Mumbai), potassium dihydrogen phosphate $\left(\mathrm{KH}_{2} \mathrm{PO}_{4}, \mathrm{AR}\right.$ grade, Merck Life Sci., Mumbai), and calcium oxide ( $\mathrm{CaO}$, AR grade, Merck Life Sci., Kolkata) as raw materials for macroelements. Borax $\left(\mathrm{Na}_{2} \mathrm{~B}_{4} \mathrm{O}_{7}\right.$, AR grade, Rankem, New Delhi), ferric oxide $\left(\mathrm{Fe}_{2} \mathrm{O}_{3}\right.$, AR grade, Merck Life Sci., Mumbai), zinc oxide (ZnO, AR grade, Merck Life Sci., Kolkata), and molybdenum trioxide $\left(\mathrm{MoO}_{3}\right.$, AR grade, E. Merck, Germany) were added in order to supply the microelements.

Glass batches of different compositions were synthesized from respective oxide (Table I). The powder ready for glass melting was prepared by dry mixing followed by wet mixing in acetone medium using an agate mortar and pestle. They were next dried and taken in a high-quality alumina crucible and fired in a muffle furnace with a programmer. In this melting operation, the temperature and time of melting were the key factors to be monitored. The important point to mention here is that we could melt the glass at a much lower temperature $\left(900-950{ }^{\circ} \mathrm{C}\right)$ with a soaking period of 30 min to $1 \mathrm{~h}$ under ambient condition. During glass melting,

Table I - Composition of different glasses (wt\%).

[Tabela I - Composição dos diferentes vidros (\% em massa).]

\begin{tabular}{cccccccccc}
\hline Glass ID & $\left(\mathrm{NH}_{4}\right) \mathrm{H}_{2} \mathrm{PO}_{4}$ & $\mathrm{MgO}$ & $\mathrm{KH}_{2} \mathrm{PO}_{4}$ & $\mathrm{CaO}$ & $\mathrm{Na}_{2} \mathrm{~B}_{4} \mathrm{O}_{7}$ & $\mathrm{Fe}_{2} \mathrm{O}_{3}$ & $\mathrm{ZnO}$ & $\mathrm{MoO}_{3}$ & Total \\
\hline GF1 & 40 & 16 & 29 & 5 & 10 & - & - & - & 100 \\
$\mathrm{GF} 2$ & 40 & 20 & 30 & 5 & - & 5 & - & - & 100 \\
$\mathrm{GF} 3$ & 40 & 20 & 30 & 5 & - & - & 5 & - & 100 \\
$\mathrm{GF} 4$ & 40 & 20 & 30 & 5 & - & - & - & 5 & 100 \\
GF5 & 49 & 12 & - & - & 15 & 10 & 8 & 6 & 100 \\
\hline
\end{tabular}


some weight loss due to the effervescences of $\mathrm{NH}_{3}$ and $\mathrm{H}_{2} \mathrm{O}$ from $\left(\mathrm{NH}_{4}\right) \mathrm{H}_{2} \mathrm{PO}_{4}$ and $\mathrm{H}_{2} \mathrm{O}$ from $\mathrm{KH}_{2} \mathrm{PO}_{4}$ occurred. The prepared glass was ground to powder using an agate mortar, then screened through two sieves with a different mesh of 330 and $425 \mu \mathrm{m}$ B.S. size and was subjected to Soxhlet distillation taking the powder in a net. The amorphous nature of the product was confirmed from X-ray diffraction (XRD) analysis. XRD experiments of glasses were performed with a Bruker D8 Discover X-ray diffractometer with $2 \theta$ ranging from $10^{\circ}$ to $90^{\circ}$ using $\mathrm{CuK} \alpha$ radiation at the wavelength of $\lambda=1.5406 \AA$.

Distillation and leaching studies: for the $\mathrm{pH}$ determination of the leachate solution, the bulk glass was powdered to $0.3-0.425 \mathrm{~mm}$ size. The $\mathrm{pH}$ of the liquid was determined by a digital $\mathrm{pH}$ meter (Sartorius, PB 11). Then 1.0 $\mathrm{g}$ of each glass sample was vapor distilled in a borosilicate glass-made Soxhlet apparatus with a $500 \mathrm{~mL}$ round bottom flask fitted with a condenser [20,21]. The distillation was carried out for a varying period of time up to a maximum of $300 \mathrm{~h}$. The heating was done in a heating mantle [22]. The measurements of $\mathrm{pH}$ of the leachate extract were carried out at regular intervals of $24,48,72,96,120,144,168,192$, $216,240,264,288$, and $300 \mathrm{~h}$. The weight after each run of leaching was measured with a 4-decimal electronic balance (Sartorius), and weight loss was determined. In order to find the leach rates, the BET surface area of the glasses was determined under liquid nitrogen temperature, and then leach rates were calculated from the total weight loss for the total cumulative leaching time [23] for GF1, GF3, and GF5 glasses. The leach rate (LR) was measured according to the following relationship:

$$
\mathrm{LR}=\frac{\mathrm{W}_{\mathrm{i}}-\mathrm{W}_{\mathrm{f}}}{\text { SA.t }}
$$

where $\mathrm{W}_{\mathrm{i}}$ and $\mathrm{W}_{\mathrm{f}}$ are the initial and final sample weights, respectively, SA is the BET surface area corresponding to the original value for each glass sample (not the areas at different leaching times), and $t$ is the time exposed to the leachant.

\section{RESULTS AND DISCUSSION}

The X-ray diffraction analysis of the melted glasses showed that the products were amorphous in nature. In melting operation, the temperature and time of melting were the principal factors to be monitored. We could melt the glass at a much lower temperature $\left(900-950{ }^{\circ} \mathrm{C}\right)$ with a soaking period of $30 \mathrm{~min}$ to $1 \mathrm{~h}$, which were earlier reported to be melted not below $1000{ }^{\circ} \mathrm{C}$ [24-26]. The effect of different modifier ions like $\mathrm{K}^{+}, \mathrm{Na}^{+}, \mathrm{Mg}^{2+}, \mathrm{Fe}^{3+}$, and $\mathrm{Ca}^{2+}$ in the basic phosphate networks glass systems on the melting temperature and time was evident; the different modifier ions (added as oxides) can lower the melting temperature of a particular composition in the phosphate system [27, 28]. Here the mechanism is that the modifier ion $\left(\mathrm{M}^{\mathrm{n}+}\right)$ dissociates the $\mathrm{P}=\mathrm{O}$ bond of network and generates anionic oxygen sites $\left(\mathrm{O}^{-}\right)$and gets attached to such sites ionically. Additionally, the variation in the melting point among different compositions in the particular phosphate system (GF1 to GF5) can be explained due to different types of modifier oxide being added.

Results of variation of $\mathrm{pH}$ : the results of $\mathrm{pH}$ studies of the leachate solution for different glasses at different time intervals are shown in the plots of Fig. 1a. The curve for GF5 ran the lowest. The slightly increasing trend in the $\mathrm{pH}$ values may be due to the mixed oxide effect of the phosphate system. The observed $\mathrm{pH}$ values were in good agreement with the equilibrium $\mathrm{pH}$ values [29] of the glass system having composition close to the present study. The range of $\mathrm{pH}$ obtained in phosphate glasses with different modifier cations covered hundreds of hours. If we consider that the following equilibrium was operated in our aqueous system:

$$
\mathrm{H}_{2} \mathrm{O} \rightleftharpoons \mathrm{H}^{+}+\mathrm{OH}^{-}
$$
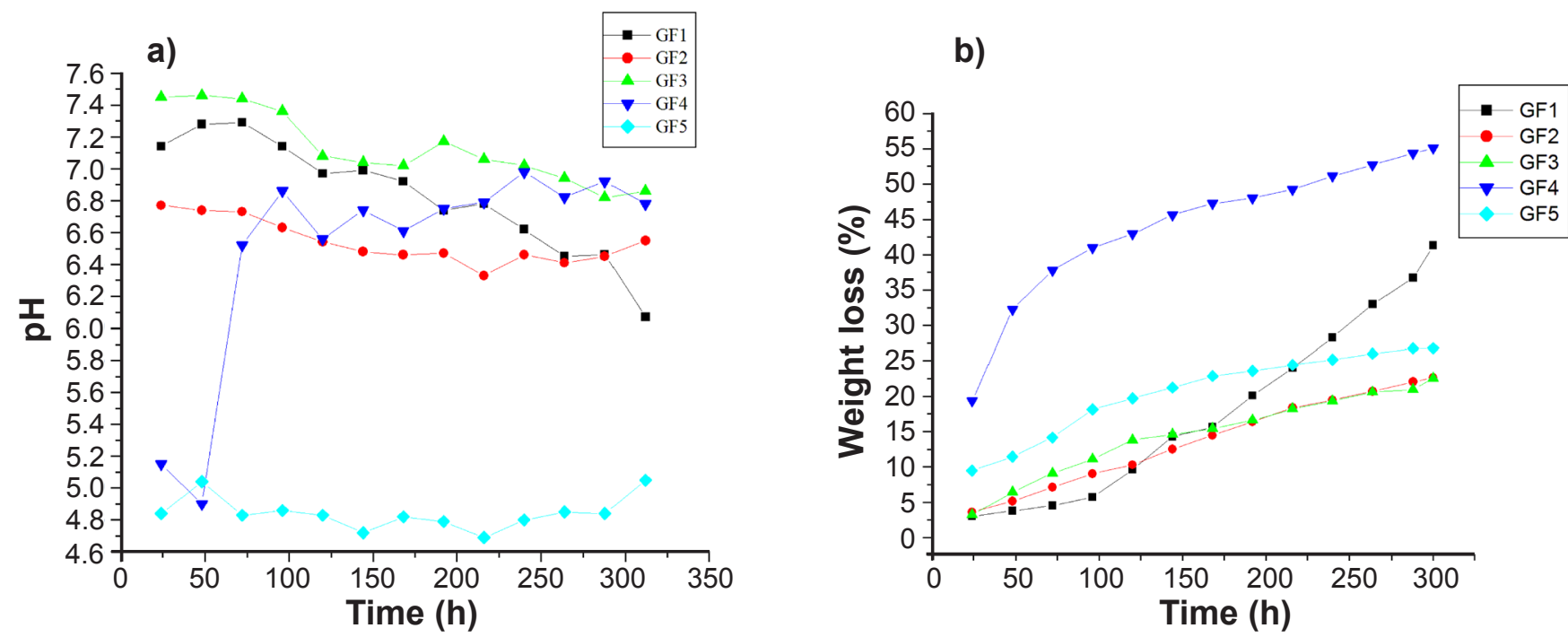

Figure 1: $\mathrm{pH}$ (a) and weight loss (b) changes of the leachate solution as a function of distillation time (Soxhlet condition) of phosphate glasses.

[Figura 1: pH (a) e perda de massa (b) da solução lixiviada em função do tempo de destilação (condição Soxhlet) dos vidros de fosfato.] 
the extent (i.e., the forward or the reverse direction) was influenced by the different modifier ions released during the leaching of the glass sample. The ionic radii (in $\AA$ ) of the different modifier ions in our case were as follows: $\mathrm{K}^{+}$ (1.38), $\mathrm{Na}^{+}$(1.02), $\mathrm{Fe}^{3+}(0.69), \mathrm{Ca}^{2+}(1.00), \mathrm{Zn}^{2+}(0.74), \mathrm{Mg}^{2+}$ $(0.72), \mathrm{Mo}^{6+}(0.59)$, and $\mathrm{B}^{3+}(0.23)$. The corresponding ionic potential (charge/radius) increased as $\mathrm{K}^{+}(0.72)<\mathrm{Na}^{+}(0.98)$ $<\mathrm{Ca}^{2+}(2.00)<\mathrm{Zn}^{2+}(2.70)<\mathrm{Mg}^{2+}(2.77)<\mathrm{Fe}^{3+}(4.69)<\mathrm{Mo}^{6+}$ $(10.16)<\mathrm{B}^{3+}$ (13.04). Now the greater the ionic potential of $\mathrm{M}^{\mathrm{n}+}$, the more it attracts $\mathrm{OH}^{-}$ions to form the corresponding hydroxides $\mathrm{M}(\mathrm{OH})_{\mathrm{n}}$, and the dissociation of $\mathrm{H}_{2} \mathrm{O}$ as above is shifted to the forward direction releasing more number of $\mathrm{H}^{+}$in the medium. Thus the resulting solution increasingly becomes acidic with decreasing the $\mathrm{pH}$ of the leachate solution [30-32]. This behavior is reflected in the observed data, i.e., leachate of the glass GF5 (with borax, $\mathrm{MoO}_{3}$, and $\mathrm{Fe}_{2} \mathrm{O}_{3}$ in the composition) showed lower $\mathrm{pH}$ value and leachate of the glass GF3 (without borax, $\mathrm{MoO}_{3}$, and $\mathrm{Fe}_{2} \mathrm{O}_{3}$ in the composition) showed maximum $\mathrm{pH}$ value. The increase in $\mathrm{pH}$ may be explained by the $\mathrm{Na}^{+}$and $\mathrm{H}^{+}$exchange corresponding to the hydration of an outer layer of phosphate chains. This reaction left excess $\mathrm{OH}^{-}$in solution, giving an initial $\mathrm{pH}$ increase, which was maintained. The $\mathrm{pH}$ change obviously depended upon the ion exchange and, therefore, the glass composition. Phosphate ions $\left(\mathrm{PO}_{4}^{3-}\right)$ can bind with $\mathrm{H}^{+}$ions to form $\mathrm{H}_{3} \mathrm{PO}_{4}$ (phosphoric acid), whereas the cations would associate with $\mathrm{OH}^{-}$ions (producing hydroxide). Therefore, due to the different glass compositions, more alkaline entities would be released, leading to a $\mathrm{pH}$ increase at the initial time of leaching. The decreasing trend in the $\mathrm{pH}$ value from 24 to $300 \mathrm{~h}$ (Fig. 1a) can be explained in the light that with a higher extent of leaching, more modifier cations are released into the solution, increasing the ionic potential leading to lowering of $\mathrm{pH}$ values.

Leaching rate of the glasses in distilled water under Soxhlet condition: leaching operation of glasses was done under Soxhlet distillation condition up to $300 \mathrm{~h}$, and it was observed that the total weight loss with respect to cumulative time (h) varied as GF4 > GF1 > GF5 > GF2 $>$ GF3. The corresponding plot is shown in Fig. 1b. The leach rates (LR) for GF1, GF3, and GF5 glasses after leaching were determined from BET surface area analysis (liquid $\mathrm{N}_{2}$ temperature). The BET surface areas (SA) were as follows: $\mathrm{SA}_{\mathrm{GF}}=0349 \mathrm{~m}^{2} \mathrm{~g}^{-1} ; \mathrm{SA}_{\mathrm{GF}}=0382 \mathrm{~m}^{2} \mathrm{~g}^{-1}$; and $\mathrm{SA}_{\mathrm{GF}}=0398 \mathrm{~m}^{2} \mathrm{~g}^{-1}$. The leach rate $(\mathrm{LR}) \mathrm{v}$ alues at $72 \mathrm{~h}$ were as follows: $\mathrm{LR}_{\mathrm{GFI}}=2.3 \times 10^{-3} \mathrm{~g} \cdot \mathrm{m}^{-2} \mathrm{~h}^{-1}$; $\mathrm{LR}_{\mathrm{GF} 3}=3 \cdot 3 \times 10^{-4} \mathrm{~g} \cdot \mathrm{m}^{-2} \cdot \mathrm{h}^{-1}$; and $\mathrm{LR}_{\mathrm{GF} 5}=6.3 \times 10^{-3} \mathrm{~g} \cdot \mathrm{m}^{-2} \cdot \mathrm{h}^{-1}$. The leach rates decreased in the order: GF5 $>$ GF3 $>$ GF1. The LR values at $48,72,96$, and $120 \mathrm{~h}$ decreased in the same order: GF5 $>$ GF3 $>$ GF1. On the other side the LR values at $144,168,192$, and $216 \mathrm{~h}$ decreased in order: GF5 > GF1 $>$ GF3. Again the LR values at 240, 264, 288, and $300 \mathrm{~h}$ decreased in the order: GF1 > GF5 > GF3. The LR values of glasses at different time intervals are shown in Table II. It is well known the water durability of phosphate glasses is improved by adding of one or more of intermediate divalent metal oxides ( $\mathrm{MO}, \mathrm{M}=\mathrm{Zn}$ and/or others) [33-36] or intermediate trivalent metal oxides $\left(\mathrm{M}_{2}^{*} \mathrm{O}_{3}, \mathrm{M}^{*}=\mathrm{Fe}\right.$ and/
Table II - Leaching rate of different glasses $\left(\mathrm{LRx} 10^{-3} \mathrm{~g} \cdot \mathrm{m}^{-2} \cdot \mathrm{h}^{-1}\right)$. [Tabela II - Taxa de lixiviação de diferentes vidros $\left(\right.$ LRx $\left.\left.10^{-3} \mathrm{~g} \cdot \mathrm{m}^{-2} \cdot \mathrm{h}^{-1}\right) \cdot\right]$

\begin{tabular}{cccc}
\hline Leaching time $(\mathrm{h})$ & GF1 & GF3 & GF5 \\
\hline 24 & 4.6 & 4.4 & 12.6 \\
48 & 2.8 & 4.4 & 7.6 \\
72 & 2.3 & 3.3 & 6.3 \\
96 & 2.2 & 3.8 & 6.0 \\
120 & 2.9 & 3.8 & 5.2 \\
144 & 3.6 & 3.4 & 4.4 \\
168 & 3.4 & 3.0 & 4.3 \\
192 & 3.8 & 2.8 & 3.9 \\
216 & 4.0 & 2.7 & 3.6 \\
240 & 4.3 & 2.6 & 3.3 \\
264 & 4.6 & 2.5 & 3.1 \\
288 & 4.7 & 2.4 & 2.5 \\
300 & 5.0 & 2.4 & 2.8 \\
\hline
\end{tabular}

or others) [37-40] to $\mathrm{P}_{2} \mathrm{O}_{5}$ network, which results in the formation of M-O-P or $\mathrm{M}^{*}$-O-P bonds leading to increase the degree of condensation of the phosphate network. $\mathrm{Fe}_{2} \mathrm{O}_{3}$ has special features, i.e., mechanically iron ions, $\mathrm{Fe}^{3+}$, can enter into the phosphate network structure replacing $\mathrm{P}^{5+}$ because of its stronger electropositivity, thus forming a $\mathrm{Fe}$ $\mathrm{O}-\mathrm{P}$ bond which strengthens the cross-bonding between the polyphosphate chains, which has better water resistance [37-42]. Furthermore, due to the smaller radius, the iron ion $\left(\mathrm{Fe}^{3+} / \mathrm{Fe}^{2+}\right)$ can hinder the larger water molecule from passing through the glass structure, therefore, significantly improving the chemical durability of the glass matrix. Therefore the glasses GF4 and GF1, which were not prepared with $\mathrm{ZnO}$ and $\mathrm{Fe}_{2} \mathrm{O}_{3}$, had higher weight losses after final leaching. Weight loss vs. cumulative time studies showed a distinct decrease in the weight loss value with an extended period of time of leaching, signifying that the extent of leaching decreased over time [42-46]. It was observed that the weight loss decreased in the order: GF4 > GF1 > GF5 > GF2 > GF3. From some other point of view, our observations on the $\mathrm{MoO}_{3}$-containing glasses the weight loss as well as leach rates were found to increase that may be due to the high mass number of the Mo atom being released during leaching.

The Mössbauer spectrum of the glass GF2 containing 5\% $\mathrm{Fe}_{2} \mathrm{O}_{3}$ showed a clear doublet with an isomer shift of 0.37 $\mathrm{mm} / \mathrm{s}$ with a quadrupole splitting (QS) of $0.76 \mathrm{~mm} / \mathrm{s}$. Such a value of isomer shift designates $\mathrm{Fe}^{2+}$ ions as observed in the Mössbauer spectrum (Fig. 2). As the glass contained $\mathrm{Fe}^{3+}$ ions during the melting process, they underwent a reduction to ferrous ions $\left(\mathrm{Fe}^{2+}\right)$. Hence a reducing environment around the iron nucleus was quite obvious. A doublet in the Mössbauer spectrum signifies an asymmetric environment around the particular nucleus viz, nitroprusside (doublet) in comparison to ferrocyanide (singlet). 


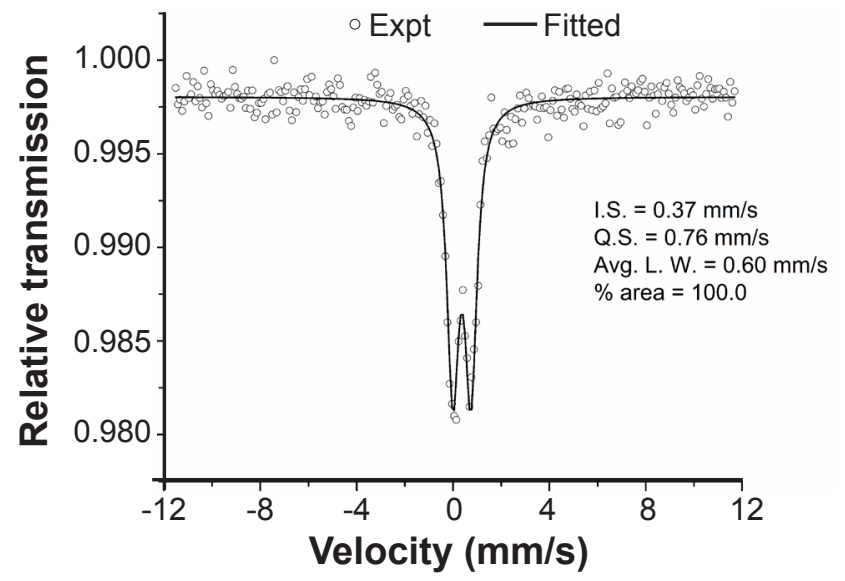

Figure 2: Mössbauer spectrum of the GF2 glass fertilizer sample. [Figura 2: Espectro de Mössbauer da amostra de fertilizante de vidro GF2.]

Application of glass fertilizer on the paddy field through pot culture: application of glass fertilizers in pot culture experiment was also carried out to khariff rice during 20182019 (Fig. 3). The study was carried out in collaboration with the Department of Soil Science and Agricultural Chemistry, Visva-Bharati, Sriniketan, West Bengal, India. The preliminarily study indicated a promising result of glass fertilizers. The studies on the efficacy of glass fertilizers will be carried out in successive crops and will be ascertained through yield, uptake, and quality of the product, and will be published later.
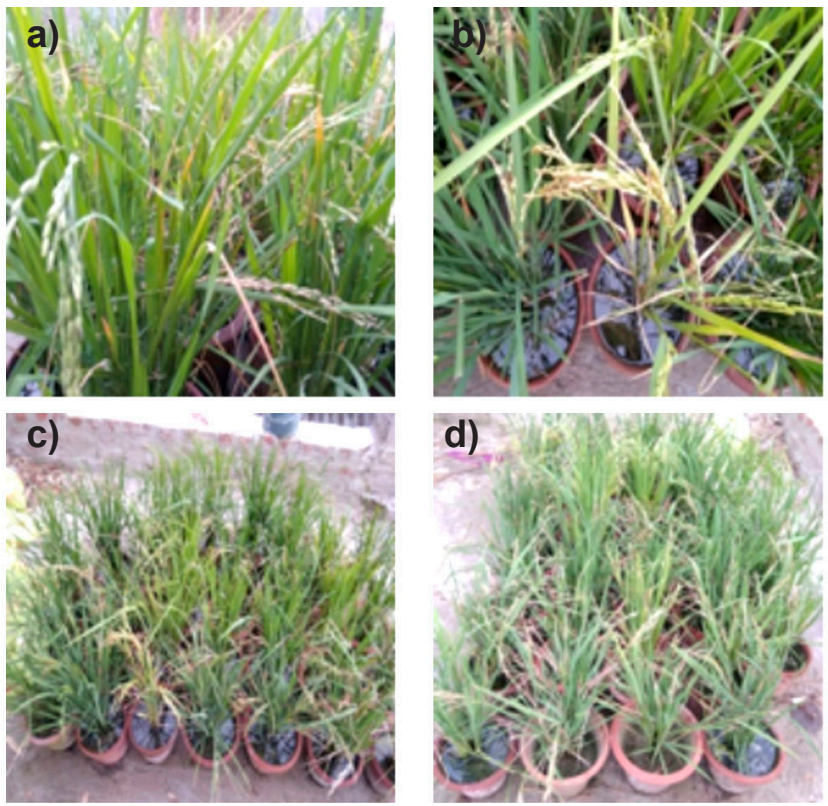

Figure 3: Pictures of pot experiment on paddy with: a) glass fertilizer GF3; b) glass fertilizer GF5; c) conventional fertilizer; and d) without any type of fertilizer.

[Figura 3: Fotos do experimento em vaso com planta de arroz com: a) fertilizante de vidro GF3; b) fertilizante de vidro GF5; c) fertilizante convencional; e d) sem qualquer tipo de fertilizante.]

\section{CONCLUSIONS}

Chemical properties of phosphate glasses depended on the glass composition. Calcium oxide $(\mathrm{CaO})$ and magnesium oxide $(\mathrm{MgO})$ were added to provide moderate chemical durability as well as for better nutrient suppliers. The nature of the product was found to be amorphous. Improvement in chemical durability was due to $\mathrm{Fe}_{2} \mathrm{O}_{3}$ content and structural role of $\mathrm{Fe}^{2+/ 3+}$, which strengthened the crossbonding between the polyphosphate chains. Thus it may be concluded that a structural rearrangement occurred in the role of $\mathrm{Fe}$ in the glass structure from modifier to former. The structure of phosphate glasses consists of Fe-O-P-O chains with modifiers intercalating the structure, bounded to non-bridging oxygen atoms. The Mössbauer spectrum for our glass fertilizer sample showed a close similarity with nitroprusside ion in comparison to that of ferrocyanide ion. The effect of modifier ions on melting temperature was evident in the present study and a much lower melt viscosity in the range from 900 to $950{ }^{\circ} \mathrm{C}$. The role of modifier in phosphate systems was very distinct in enhancing its leach resistance. The change of the $\mathrm{K}_{2} \mathrm{O} / \mathrm{P}_{2} \mathrm{O}_{5}$ ratio was the main key factor in controlling water solubility and chemical durability. In the abnormal glass properties such as fast dissolution in aqueous solution, it was presented that the glass can be a good candidate for agriculture fertilizer. Most important of all, water and soil pollution hazards are minimized, and the economics of fertilizer use is significantly improved. The cumulative weight loss, i.e., leaching or leaching rate of the glasses, depended on the addition of modifier oxides into their compositions. It is shown that the glass with $\mathrm{MoO}_{3}$ had maximum leach rate value, which may also be due to the high atomic weight of Mo, which was leached out under Soxhlet condition. In general, the addition of alkaline earth oxides increases the corrosion of phosphate glasses, whereas the addition of intermediate oxides decreases the corrosion of phosphate glasses. It was shown that after the application of the glass fertilizer, the growth and production of the khariff paddy was better than the normal application of the conventional fertilizers.

\section{ACKNOWLEDGMENTS}

Time to time discussions with Dr. J. Mukerji, retired Scientist CSIR-CGCRI, Kolkata is duly acknowledged. The service rendered by Dr. Omprakash Chakrabarti, Chief Scientist \& Head, TCC and Dr. Asim Chakrabarti, Scientist, CSIR-CGCRI, Kolkata in performing the surface area analyses; Dr Dipankar Das, UGC-DAE Consortium for Scientific Research Kolkata Centre in performing the Mössbauer analyses are gratefully acknowledged.

\section{REFERENCES}

[1] G. Hazra, Sustain. Environ. 1, 1 (2016) 54.

[2] J.A. Camargo, A. Alonso, Environ. Int. 32 (2006) 831.

[3] R.N. Roy, A. Finck, G.J. Blair, H.L.S. Tandon, "Plant nutrition for food security: a guide for integrated nutrient management", FAO Fert. Plant Nutr. Bull. 16, FAO, Rome (2006). 
[4] W. Vogel, Chemistry of glass, Am. Ceram. Soc., Columbus (1985).

[5] L.L. Hench, R.J. Splinter, W.C. Allen, T.K. Greenlee, J. Biomed. Mater. Res. A 5 (1971) 117.

[6] L.L. Hench, Ceramurgia VII, 5 (1977) 253.

[7] Y. Zhang, J.D. Santos, J. Non-Cryst. Solids 272 (2000) 14.

[8] I. Waclawska, M. Szumera, J. Alloys Compd. 468 (2009) 246.

[9] G. Karapetyan, K. Karapetyan, L. Maksimov, "Glassy environmentally friendly fertilizers of prolonged action", Phosphorus Res. Bull. 15 (2004) 60.

[10] R.K, Brow, J. Non-Cryst. Solids 263-264 (2000) 1.

[11] J.C. Cole, M.W. Smith, C.J. Penn, B.C. Cheary, K.J. Conaghan, Sci. Hortic. 211 (2016) 420.

[12] B. Mandal, T. Das, G. Hazra, J. Emerg. Technol. Innov. Res. 5, 11 (2018) 698.

[13] G. Hazra, T. Das, Glob. J. Sci. Front. Res. B Chem. 14, 4 (2014) 33.

[14] M. Elisa, B.A. Sava, A. Diaconu, L. Boroica, D. Ursu, I. Stamatin, F. Nastase, C. Nastase, C. Logofatu, Glass Phys. Chem. 35, 6 (2009) 596.

[15] M. Sava, B.A. Sava, L. Boroica, A.L. Diaconu, D. Ursu, M. Elisa, Sci. Papers Ser. A Agron. LIII (2010) 187.

[16] M. Elisa, R. Iordanescu, B.A. Sava, G. Aldica, V. Kuncser, C. Valsangiacom, G. Schinteie, F. Nastase, C. Nastase, V. Bercu, A. Volceanov, S. Peretz, J. Mater. Sci. 46, 6 (2011) 1563.

[17] M. Cerchez, L. Boroica, I. Boroica, in Proc. First Balkan Conf. Glass Sci. Technol., Volos (2000) 227.

[18] M. Elisa, B.A. Sava, C. Iordanescu, I. Feraru, C. Vasiliu, M. Calin, A. Diaconu, D.L. Ursu, L. Boroica, Z. Plaiasu, F. Nastase, C. Nastase, A. Dumitru, Optoelectron. Adv. Mater. Rapid Commun. 4, 9 (2010) 1301.

[19] B. Mandal, G. Hazra, T. Das, Glob. J. Eng. Sci. Res. 6, 4 (2019) 14.

[20] J. Mukerji, A.S. Sanyal, Glass Technol. 45, 3 (2004) 117.

[21] B.A. Sava, I. Boroica, M. Sava, M. Elisab, I. Vasiliub, F. Nastasec, C. Nastasec, R. Medianu, J. Optoelectron. Adv. M. 13, 11-12 (2011) 1534.

[22] M.A. Azooz, H.A. El Batal, M. Abd El Moneim, Trans. Indian Ceram. Soc. 64 (2005) 101.

[23] T. Yanagi, M. Yoshizoe, N. Nakatsuka, J. Nucl. Sci. Technol. 25, 8 (1988) 661.

[24] G.K. Marasinghe, M. Karabulut, C.S. Ray, D.E. Day, D.K. Shuh, P.G. Allen, M.L. Saboungi, M. Grimsditch, D. Haeffner, J. Non-Cryst. Solids 263-264 (2000) 146.

[25] J. Hudgens, R.K. Brow, D.R. Tallatant, S.W. Martin, J. Non-Cryst. Solids 223, 1-2 (1998) 21.
[26] G. Hazra, T. Das, P. Mitra, in Proc. NUCAR-2011, Visakhapatnam (2011) 449.

[27] G. Hazra, Int. J. Adv. Res. Eng. Appl. Sci. 2, 12 (2013) 30.

[28] P.P. Malik, G. Hazra, P. Mitra, T. Das, Prog. Theor. Appl. Phys. 1 (2013) 1.

[29] M.G. Mesko, D.E. Day, B.C. Bunker, in "Science and technology for disposal of radioactive tank wastes", W.W. Schulz, N.J. Lombardo (Eds.), Springer, New York (1998) 379.

[30] D.E. Day, Z. Wu, C. Ray, "Chemically durable glasses for vitrifying phosphate containing simulated nuclear wastes", Final Techn. Rep., Pacific Northwest Nat. Lab., USA (1995).

[31] T. Yanagi, M. Yoshizoe, N. Nakatsuka, in WM'02 Conf., Tucson (2002).

[32] G. Hazra, A. Ghosh, T. Das, P. Mitra, Int. J. Adv. Res. Eng. Appl. Sci. 3, 8 (2014) 16.

[33] D. Rébiscoul, V. Tormos, N. Godon, J.P. Mestre, M. Cabie, G. Amiard, E. Foy, P. Frugier, S. Gin, Appl. Geochem. 58 (2015) 26.

[34] G.S. Frankel, J.D. Vienna, J. Lian, J.R. Scully, S. Gin, J.V. Ryan, J. Wang, S.H. Kim, W. Windl, J. Du, NPJ Mater. Degrad. 2 (2018) 15.

[35] P. Dillmann, S. Gin, D. Neff, L. Gentaz, D. Rebiscoul, Geochim. Cosmochim. Acta 172 (2016) 287.

[36] M. Fournier, S. Gin, P. Frugier, J. Nucl. Mater. 448 (2014) 348

[37] I.S. Muller, S. Ribet, I.L. Pegg, S. Gin, P. Frugier, Ceram. Trans. 176 (2006) 191.

[38] H. Yang, M. Fu, B. Wu, Y. Zhang, R. Ma, J. Qian, Sci. Technol. Nucl. Install. 2019 (2019) 4936379.

[39] J.H. Cho, Y. Eom, T.G. Lee, J. Hazard. Mater. 278 (2014) 474

[40] W. Huang, D.E. Day, C.S. Ray, C.-W. Kim, A. MogusMilankovic, J. Nucl. Mater. 327, 1 (2004) 46.

[41] D.E. Day, C.S. Ray, "A review of iron phosphate glasses and recommendations for vitrifying hanford waste", INL/ EXT-13-3089, Idaho Nat. Lab., USA (2013).

[42] P.Y. Ship, Mater. Chem. Phys. 80 (2003) 299.

[43] X. Fang, C.S. Ray, G.K. Marasinghe, D.E. Day, J. NonCryst. Solids 283 (2001) 162.

[44] T. Yanagi, M. Yoshizoe, K. Kuramoto, J. Nucl. Sci. Technol. 26 (1989) 948.

[45] G. Hazra, P. Mitra, T. Das, Trans. Indian Ceram. Soc. 2, 78 (2019) 1 .

[46] A. Ghosh, G. Hazra, P. Mitra, T. Das, Orient. J. Chem. 30, 1 (2014) 87.

(Rec. 20/10/2019, Rev. 18/01/2020, 17/02/2020, Ac. $07 / 03 / 2020)$ 